\title{
Alice in Accounting Land: The Adventure of Two Economic Historians in Accounting Records of the 19th Century
}

\author{
Luciana Suarez Lopes \\ Ph.D Professor, Department of Economics, School of Economics, Business and Áccounting, University of São Paulo. \\ E-mail: Islopes@usp.br
}

Anne Gerard Hanley

Associate Professor, Department of History, Northern Illinois University.

E-mail: ahanley@niu.edu

Received on 08.08.2013 - Desk acceptance on 08.14.2013 - $3^{\text {th }}$ version approved on 03.30.2014

\begin{abstract}
This article aims to share our experience of working with São Paulo's municipal budgets published during the $19^{\text {th }}$ century and discuss the difficulties of using this kind of source to analyze the municipal public finance from a historical perspective. The budget laws published draw the researcher's attention because they are abundant and relatively easy to work with, providing a huge documentary set that may be used as a means for studies in the fields of economic history, political history, and cultural history within the imperial period. These laws are printed, therefore, readable, and easily accessible through the digital web portal Acervo Histórico da Assembleia Legislativa do Estado de São Paulo [Historical Collection of the São Paulo State Legislative Assembly]. They detail the origins and destinations of public resources, municipality by municipality, allowing the researcher to reconstruct the financial life of municipalities, identifying changes in time and space of the fortunes of the $19^{\text {th }}$-century São Paulo state communities. However, may we really trust these budgets? Conversations and collaborations between two researchers showed that these accessible, readable, and abundant sources are not as appropriate as they seem at first glance. This article reports our troubled and even contradictory journey into the world of municipal public accounting, in order to detail our findings and provide a warning on these sources. A comparative methodology between budget laws and handwritten balance sheets was used at time intervals of 1,2 , and 3 years, in search of correlations and adjustment patterns between budgeted and spent amounts of money. Our experience has shown that budget laws do not have much in common with the actual financial experience of municipalities within the imperial period, therefore, they are not the most appropriate sources to know the financial daily life in the $19^{\text {th }}$-century São Paulo state villages.
\end{abstract}

Keywords: Public finance. Municipality. Balance sheet. Budget. 


\section{INTRODUCTION}

This article aims to share our experience of working with the São Paulo's municipal budgets published during the $19^{\text {th }}$ century, discuss the difficulties of using this kind of source to study the municipal public finance from a historical perspective, besides analyzing the possible research methodologies in the absence of other more appropriate sources, such as balance sheets and handwritten financial statements.

Historical budgets draw the researcher's attention because they are abundant and easy to work. The São Paulo state budget laws, drafted and published annually by the Legislative Assembly, back then from the Province of São Paulo, constitutes a huge documentary set that may be used as a means for studies in the fields of economic history, political history, and cultural history within the imperial period. These laws are printed and, therefore, readable, and easily accessible through the digital web portal Acervo Histórico da Assembleia Legislativa do Estado de São Paulo [Historical Collection of the São Paulo State Legislative Assembly ${ }^{1}$. They detail the origins and destinations of public resources, municipality by municipality, allowing the researcher to reconstruct the financial life of municipalities and identify changes in time and space of the fortunes of the $19^{\text {th }}$-century São Paulo state communities.

However, can we really trust these budgets? Many conversations and collaborative research between two researchers showed that, perhaps, these accessible, readable, and abundant sources are not as appropriate as they seem at first glance. This may pose a major problem for the Brazilian history because the government's revenue and expenditure balance sheets - primary source for understanding the public economy and its political and social branches in the state formation within the period after independence - were regularly printed only at the general government level. These reports provide the essential data for interpretations of the national administrative, financial, and economic history, as well as of the balance between the imperial and the provincial powers ${ }^{2}$. The development of research like ours, which seeks to study the effects of tax structure on the economic life of the municipality - historical space where the national policies have had their impact on local and regional economic development - exists only for a few isolated municipalities $^{3}$. Larger and comparative studies are hampered by the absence of sources, this absence might be avoided by using the abundant and affordable budgets as a proxy of revenue and expense balance sheets. Currently, this concern takes greater proportions given the digitization and online availability of laws and a large number of documents from the imperial period. The greater availability of budgets through scanning will increase their search and application in historical studies. Our experience with both documentary sets, budget laws and handwritten financial statements, has raised our awareness about the possibility that historiography based on budget laws contains serious errors. Thus, given the absence of specific studies, understanding how such sources registered the past economic activity becomes crucial to get a better grasp of the past.

The starting point of this exercise consisted in the differing results achieved by the researchers in their individual works. After identifying these discrepancies, the focus became understanding the reason of these differences. We noticed early that the ex-ante and ex-post values did not line up; budgets always predicted positive balance sheets while the statements often reported deficits. Then, the research question was finding out whether there was some pattern in the preparation of budgets - for instance, budgets for a given year prepared by considering the financial statements of previous years - and then start thinking of any method that could be applied so that the budget laws could be used as a substitute for the balance sheets or financial statements. Our hypothesis was that the activity of preparing budgets had been improved by considering financial statements, increasing year after year the ability of public officials to predict and estimate future results. Thus, according to our hypothesis, the results in Year 1, for instance, could have been used to establish the budget for Year 2 or 3 . This might provide the current researcher with a tool that allows her/him to consider the budgeted amounts in a given year as a proxy for actually spent amounts in other years.

At the end of the survey, we concluded that our hypothesis could not be accepted. We could not identify any kind of pattern or relationship between the budgeted amounts in the budget laws and the amounts presented in financial statements. Therefore, it became clear that budget laws are not a suitable source for studying the São Paulo's municipal public finance during the $19^{\text {th }}$ century.

Thus, this article reports our troubled and even contradictory journey into the world of municipal public accounting, in order to detail the steps we have followed, as well as the results we achieved. Our experience has shown that budget laws do not have much in common with the actual financial experience of municipalities within the imperial period, therefore they are not a suitable source. Surveys in the field of municipal economic and financial history must use budgets very carefully - we even discourage their use seeking, instead of them, the balance sheets or handwritten financial statements.

The Historical Collection of the São Paulo State Legislative Assembly, as well as its databases can be accessed on: <http://www.al.sp.gov.br/web/acervo2/index_acervo.htm>.

Among the works devoted to the study of the evolution of tax structure and its effect on the distribution of resources in Brazil, we may cite: Mircea Buescu, Organização e administração do Ministério da Fazenda no Império (1984); Augusto Olympio Viveiros de Castro, História Tributária do Brasil (1989); José Murilo de Carvalho, Teatro de sombras (2003); Liberato de Castro Carreira, História financeira e orçamentária do Império do Brazil desde a sua fundação, precedida de alguns apontamentos acerca da sua Independência (1889); Pedro Octávio Carneiro da Cunha, Politica e administração de 1640 a 1763 (1973); Guilherme Deveza, Politica tributária no periodo imperial (1971); Miriam Dolhnikoff, O pacto imperial (2005); Max Fleiuss, História administrativa do Brasil (1925); Richard Graham, Government expenditures and political change in Brazil, 18801889 (1977); Alfredo d'Escragnolle, História administrativa do Brasil (in Taunay, 1974); and André Villela, Distribuição regional das receitas e despesas do Governo Central no II Reinado, 1844-1889 (2007). About the São Paulo State tax structure, see Viviane Tessitore, As fontes da riqueza pública: tributos e administração tributária na Província de São Paulo (1832-1892) (1995).

Among the studies that have devoted to analyze isolated cases of municipalities, we can mention the works by Nelson Hideiki Nozoe, São Paulo: economia cafeeira e urbanização (1984) and Vida Econômica e finanças municipais da capital paulista na época imperial (2004); Julio Manuel Pires, Um estudo de história econômica regional sob a ótica das finanças públicas (1994); Luciana Suarez Lopes, Ribeirão Preto: a dinâmica da economia cafeeira de 1870 a 1930 (2011); and Maria Isabel Basilisco Célia Danieli, Economia mercantil de abastecimento e rede tributária: São Paulo, séculos XVIII e XIX (2006). 


\section{THE ISSUE OF BUDGET LAWS}

The issue that gave rise to this article came from the comparison that the authors have made regarding the results of two articles authored by them. Both dealt with the municipal public accounting in $19^{\text {th }}$-century São Paulo state. One employed published budget laws, kept in the Arquivo Histórico da Assembleia Legislativa do Estado de São Paulo [Historical Archive of the São Paulo State Legislative Assembly] (ALESP). The other used balance sheets or handwritten financial statements preserved in the same archive.

In the first of these papers, "A Failure to Deliver: $\mathrm{Mu}$ nicipal Poverty and the Provision of Public Services in Imperial São Paulo, Brazil 1822-1889”, Anne Hanley analyzed São Paulo's municipal public accounting by using handwritten balance sheets (ex-post), in order to understand how the provision of public resources - such as water, sewage, infrastructure, safety, and health - took place in the $19^{\text {th }}$ century in Brazil ${ }^{4}$. The results showed that the Municipal Councils, during the $19^{\text {th }}$ century, failed to adequately supply their villages with the needed public goods mentioned above. Such a result was due, to a large extent, to the subordinate position they occupied before the provincial authorities. Other authors have also identified the subordinate position of Municipal Councils and their difficulties in meeting the population's demands. The lack of municipal autonomy and the gap existing in the legislation on tax powers have led to a condition in which the resources available to them were not sufficient to meet their needs (according to Montoro, 1974; Nozoe, 1984, 2004).

In the second paper that has led to this article, "As Leis Orçamentárias e a Estrutura Tributária dos Municípios Paulistas, 1834-1850" [Budget Laws and the Tax Structure of São Paulo State Municipalities, 1834-1850], Luciana Suarez Lopes also analyzed the São Paulo state municipal public accounting, but in search of fundraising patterns within the period from 1834 to 1850 . Based on municipal budgets published by ALESP (ex-ante), it was possible to study the municipal sources of revenue, identifying the main taxes and analyzing how this structure has changed over the years ${ }^{5}$.

To our surprise, according to the budgets, it was not possible to identify the aforementioned lack of resources, registered both by historiography and the first article considered herein. Contrary to expectations, a significant percentage of budgeted revenue appeared under the heading balances and surpluses from previous years, which had its average share estimated in $24.9 \%$ of the total budgeted amount.

When comparing these results, the authors started asking how could two researchers who analyze the $19^{\text {th- }}$ -century São Paulo state municipal public accounting reach such different results? The search for answering to this question has led us to a journey into the accounting wonderland of the $19^{\text {th }}$ century.

We are economic historians and, therefore, a bit unfamiliar with the literature in accounting history, so we did a search on the main journals in accounting history looking for papers that could help us answering the question. The sparse literature on the subject tends to analyze accounting in the context of the State's role in the economy or the relationship between the federal and state government ${ }^{6}$. Rather punctual literature is concerned with the discontinuities between budgeted amounts and provided amounts at the level of national budgets, and it does not tend to worry about the reasons for variation between the two sources ${ }^{7}$. A recent study conducting a systematic review of academic studies in accounting history with a focus on local history has found that

[...] from 1965 to 2009 , it was possible to confirm that accounting history research on local government remained under-investigated and, although strongly based on the archive, the traditional approach prevailed, with only a few articles adopting a theoretical framework to interpret the findings (Gomes \& Sargiacomo, 2013, p. 440).

We did not find any scholarly article concerned with the characteristics of the primary sources ex-ante and ex-post and their branches for historical interpretation that might serve as a guide.

So, we decided to systematically analyze the sources considered in each of our individual studies comparing approaches and results and discussing the practices of clerks who prepared the budgets and balance sheets. We concluded that our journey would be much more strange and complicated than each of us initially thought.

We assume that this problem has not been identified before because of the difficulty of access to primary sources prior to the digital age, which, by requiring several visits to regional and state archives to search and collect such documents, led the researcher to choose to use this or that source. Only in recent years, after the digitization of collections handwritten and printed in the case of the archives in the Legislative Assembly of São Paulo - the search and collection of huge amounts of sources has become a reality. Still, even after making access easier and improving the search engines by keyword, the handwritten documents are difficult to understand and hard to transcribe, increasing the likelihood that the researcher choose to use the printed budgets.

\footnotetext{
This article analyzes manuscript balance sheets, official letters, formal petitions, and requests from seven municipalities in western São Paulo state between 1828 and 1889 . The municipalities selected for the study were: Amparo, Araraquara, Campinas, Franca, Ribeirão Preto, Rio Claro, and São Carlos.

The article was prepared considering the municipal budget laws published by ALESP in even years, within the period from 1834 to 1850 . Data were collected on all São Paulo state municipalities of the period, whose number ranged from 46 to 56 . The analyses resulted in the article, presented at the $9^{\text {th }}$ International Congress of the Brazilian Studies Association, held in New Orleans, in March 2008.

An example might be article by Alessandro Giosi, Considerations on the Evolution of the National Budget Functions: From Internal Relevance to External Value (2007).

See, for instance, Geoff Burrows and Phillip E. Cobbin, Budgetary and financial discontinuities: Iraq 1920-32 (2011).
} 


\section{THE SURVEY OF SOURCES}

We take as a starting point the question: Why was there a difference in the results? The first study focused on handwritten balance sheets and financial statements. The second, on the municipal budget laws published by ALESP. Working with handwritten balance sheets and financial statements is slow and hard. These documents were prepared by ordinary people with no technical training. They were usually figures with a certain economic and political power at the local level who, due to this reason, held public service positions, being responsible, among other duties, to sketch budgets and financial statements both regarding revenue and local expenditures. In turn, municipal budget laws, even if they were prepared having the documentation submitted by municipalities as a basis, underwent analysis by the Committee on Budget and Finance of the Provincial Legislative Assembly. Annually approved, they were usually published in March, providing for the authorized revenue and expenditure regarding the financial year, which opened on October, $1^{8}$. Very easy to use and systematize, budget laws allow studies with a larger number of municipalities. To examine the set of São Paulo state municipalities, the laws seem, at first glance, the most appropriate source of data.

Thus, if the results in the articles were so different, the problem might be in the sources. Would it be plausible to think that budgets and balance sheets were so different? The most logical thing would be assuming that in the beginning, in 1834, when it became mandatory to send these municipal financial reports to the Legislative Assembly, perhaps there were more significant differences. Nevertheless, the rationale makes us believe that, over the years, these disparities were slowly adjusted, turning the budget into a realistic prediction both of revenue and expenditure. However, we did not observe this. It seemed as if the values refused to align properly in organized patterns.

It became clear that to solve the problem there was a need to prepare an analysis together. Seeking answers to the various questions raised, 2011, the article "Can public accounts be trusted? Evidence from the historical record in São Paulo, Brazil 1835-1850" was prepared and presented at the $11^{\text {th }}$ International Congress of the Brazilian Studies Association, in September 2012 (Hanley \& Lopes, 2012). There, we study how the $19^{\text {th }}$-century municipal public accounting worked in fact, through the comparative analysis of budgets, financial statements, requests of additional funding submitted to the Provincial Legislative Assembly by the towns of Bananal, Campinas, Franca, Araraquara, Apiaí, and Iguape ${ }^{9}$. These requests have provided important evidence of lack of municipal resources in the article by Hanley (2013), because they always asked subsidies for investment in municipal infrastructure with values far beyond the annual revenue. Then, based on the analysis of budgets, along with an analysis of the balance sheets and requests of additional funding in the selected municipalities and working together, it was possible to confirm the respective individual results, making clear that the discrepancy of such results only reflected the diversity of sources.

Budget analysis showed that, in theory, the sources of revenue might be sufficient to meet the municipal expenditures. The presence of balances and surpluses was confirmed: almost all towns in all the years had in the budgeted revenue some remaining balance from previous years, sometimes reaching half or even more than half of the budgeted revenue in some year within the period considered. On average, the balances and surpluses of our sample of towns - our six selected cases - represent around $27.3 \%$ of budgeted revenue, and the provincial average was calculated at $22 \%$.

Now, looking from the perspective of expenditure, the existence of passive debts, we found a low level of indebtedness of municipalities. Not all municipalities had passive debts within the period, and those that had not were debtors in all years within the period. Thus, the percentages achieved by passive debts were lower than those calculated for balances and surpluses. The average percentage of the sample debt reached $11.3 \%$, while the average for all municipalities of the province was $6.1 \%$. The analysis of budget laws showed that the selected municipalities - Bananal, Campinas, Franca, Iguape, Apiaí, and Araraquara - had balanced public budgets, and this result could be generalized for the province as a whole.

However, considering the handwritten financial statements, the results were different. These documents showed that, in fact, there was a shortage of resources. In all cases there were fiscal years in which municipalities spent more than collected, needing balances of previous years to deal with expenditure. In some cases, nevertheless, the municipalities registered deficits even relying on such balances ${ }^{10}$. Such evidence of lack of resources was corroborated by the identification of several requests for additional funding submitted by towns to the Provincial Assembly. They were funding requests for the construction of cemeteries, bridges, roads, pathways, and other public improvements. Such requests may be understood as a call so that the province financially contributed to the municipality, in order to enable it to provide the population with public services that, in theory, should be its responsibility. Thus, if budget laws showed a situation where municipal revenue was sufficient to meet local demands, the handwritten financial statements and requests for additional funding show a very different situation.

\footnotetext{
The financial year began on October, 1, and ended on September, 30. At the end of the 1840 s this pattern changed. The adjustment appears in the budget for 1850 , where revenue and expenditure were estimated for a period of 15 instead of 12 months.

Considering that the province of São Paulo consisted within the period from 1834 to 1850 in a number of towns or villages ranging from 46 to 56 , we chose to analyze a sample of these locations. This sample was selected according to the availability of budgets, financial statements, requests of funding within the period from 1835 to 1850 . Through the geographical division of the province of São Paulo proposed by José Francisco de Camargo in the book Crescimento da população no Estado de São Paulo e seus aspectos econômicos (1981), a municipality by zone was chosen, except the provincial capital (1 $1^{\text {st }}$ zone), considering that, because it was the capital, the municipal government might not be subject to the same conditions and political arrangements that the other villages back then, and three regions whose foundation occurred in a period after that took into account by the article, namely, the $6^{\text {th }}, 7^{\text {th }}$, and $8^{\text {th }}$ zones.

All cases, except lguape, registered at least one deficit, even including the balances. If we compare the ordinary revenue to ordinary expenditure in each case and each year, the number of negative fiscal years increases dramatically.
} 


\section{BUDGETS VERSUS BALANCE SHEETS: A METHODOLOGY}

Clearly, budgets represent an optimistic interpretation of public municipal finance, an interpretation that did not reflect a much more complex and even pessimistic reality. The temptation might be to work with these budget laws because they are so accessible, readable, and abundant, but our research has led us to the conclusion that this would not be possible without understanding the relationship between the budgeted values and the provided values. In search of an alternative approach that could allow the use of budget laws to bring the budgeted values from the provided values, we chose five towns. They were Araraquara, Bananal, Campinas, Franca, and Iguape. The hypothesis to be tested is that data from the financial statement of Year $1 \mathrm{mi}$ ght provide the basis for future budgets. Do the councilors prepare their future budgets based on the results of recent financial statements? If this hypothesis could be confirmed, the historian could use budget laws with a lag, in order to estimate results from the balance sheet. Thus, accessible, readable, and abundant budgets might also become a reliable source for understanding the financial life of the São Paulo state municipalities.

To do this, we deconstructed both budgets and financial statements, creating standardized groups of revenue and expenditure, to find out if the financial statements in Year 1 had some relation to the budgets of Years 2 or 3. Thus, revenues were divided into ordinary revenue, balances and surpluses, and active debt. Expenditure was divided into ordinary expense and passive debt ${ }^{11}$. Then, the budgeted values were compared to the values actually collected or spent for each of the established categories, as well as the total value of all revenues and expenses, in order to verify whether the results of a given financial year were the basis for the preparation of some future budget. This comparison was made according to the following criteria:

- Financial Statement of Year 1 versus Budget of Year 1 (e.g. Financial Statement of 1836 versus Budget of 1836), generating Type 1 comparisons;

- Financial Statement of Year 1 versus Budget of Year 2 (e.g. Financial Statement of 1836 versus Budget of 1837), generating Type 2 comparisons; and

- Financial Statement of Year 1 versus Budget of Year 3 (e.g. Financial Statement of 1836 versus Budget of 1838), generating Type 3 comparisons.

Type 1 comparisons (Financial Statement of Year 1 versus Budget of Year 1) show the existing adjustment between revenue and expense expectations and the amounts actually collected and spent. This comparison measures the ability of local administrators to correctly predict or estimate revenues and expenses in a given year. Type 2 and 3 calculations show that the financial statement of Year 1 was used as a means for the preparation of budgets for future years. Thus, Type 2 comparisons (Financial Statement of Year 1 versus Budget of Year 2) show the results of Year 1 were took into account for the preparation of the budget in the subsequent year. Similarly, Type 3 comparisons show whether the financial statements of Year 1 accounts were took into account for the preparation of the budget of Year 3, the assumption here is that, perhaps, local administrators needed more time to incorporate the results of the accounts of financial statements in the preparation of future budgets.

The number of budgets and financial statements available for each town, as well as the number of comparisons of Types 1,2, and 3 that the sources allowed to be prepared can be observed in Table 1 .

Table $1 \quad$ Number of budgets and financial statements, and Type 1, 2, and 3 comparisons. (Values in absolute numbers)

\begin{tabular}{|c|c|c|c|c|c|}
\hline Municipalities & Budgets available & Financial statements available & Type 1 comparisons & Type 2 comparisons & Type 3 comparisons \\
\hline Araraquara & 14 & 13 & 13 & 11 & 10 \\
\hline Bananal & 14 & 11 & 10 & 9 & 8 \\
\hline Campinas & 14 & 9 & 8 & 7 & 7 \\
\hline Franca & 14 & 11 & 10 & 9 & 8 \\
\hline Iguape & 13 & 8 & 7 & 6 & 5 \\
\hline
\end{tabular}

Then, the results of the three calculation types were examined to verify two aspects: a) which financial year reflects more closely the revenues and expenses included in the financial statements of municipalities; and b) which revenues/expenses were better estimated.

We examined the results of the three calculation types to see which reflected more closely the results provided by municipalities and to find out whether some components of the budgeted revenue/expenditure were closer to the values provided. Thanks to the previous work ("Can public accounts be trusted? Evidence from the historical record in São Paulo, Brazil 1835-1850"), for instance, we knew that the heading active debts was not a reliable source of revenue, because these values were rarely collected in their entirety into the public coffers (Hanley \& Lopes, 2012). Thus, we start from the hypothesis that we could get a clo-

The groups ordinary revenue and ordinary expense gather all headings except active debt, balances and surpluses, and passive debt. Taxes and fees charged slightly vary from town to town, as well as payments and expenses. However, generally, the group ordinary revenue consists of the following taxes: consumption taxes, such as yerba mate, aguardiente, tobacco, and cotton cloths; various licenses; revenue from the trade of food and beverages; taxes on shops and businesses in general; revenue by animal slaughter; testing weights and measures; and various fines. Likewise, in general terms, the group ordinary expenses consists of the following expenses: rent of buildings; payment of wages and bonuses; testing weights and measures; cost of elections, jury duty time, and other costs; public and sanitation works; prison maintenance and feeding of prisoners. 
ser relation between the budgeted and provided values if we separated the most regular accounts from the less reliable accounts. Thus, we did these calculations for the major categories of revenues and expenses previously mentioned (ordinary revenue; balances and surpluses; active debt; ordinary expense; and passive expense).

\section{RESULTS}

The results were discouraging for those researchers who seek to use budget laws, abundant, easily accessible, and likely to be quickly tabulated, given the ease of reading; at the expense of those not so easy to read - and, in some cases, even unreadable - handwritten financial statements. Calculations have revealed that none of the suggested methods - Type 1, 2, or 3 comparisons - produced results which made clear that the budgets either predicted values to be collected and spent or properly reflected the values received and registered in financial statements. In addition, the results for each category of revenue/expenditure, related to each of the selected municipalities, were variable, with no tendency for standardization over time and the probable experience gain of local public administrators when managing their financial resources.

These results show that: agents responsible for pre-
After doing calculations for the major categories of revenue and expenditure, we started analyzing the various headings that made up the revenue and ordinary expenses of the five selected villages, keeping the previously established pattern of analysis: Type 1,2, and 3 comparisons, such as previously specified. paring the budgets were not able to adequately predict revenue and expenditure in the current financial year (Financial Statement of Year 1 versus Budget of Year 1); and they also did not use the result of financial statement to budget values for the subsequent financial years (Financial Statement of Year 1 versus Budget of Year 2 or Financial Statement of Year 1 versus Budget of Year 3). Moreover, the disparity in results did not allow the identification of a pattern, there is no traces of refinement of financial skills among municipal administrators. Volatility, as well as the rarity of cases where we observed a certain adequacy of budgets to past financial statements - considering a variation of $10 \%$ for more or less in the budgeted values - is a clear demonstration of the poor reliability of estimates as substitutes of handwritten financial statements for historical research. Thus, tables 2 , 3 , and 4 show the results of comparisons.

Table 2 Type 1, 2, and 3 comparisons related to ordinary revenue (except active debts and balances and surpluses)

\begin{tabular}{|c|c|c|c|c|c|c|c|c|c|}
\hline \multirow[t]{2}{*}{ Municipalities } & \multicolumn{3}{|c|}{ Type 1 comparison } & \multicolumn{3}{|c|}{ Type 2 comparison } & \multicolumn{3}{|c|}{ Type 3 comparison } \\
\hline & $\begin{array}{c}\text { Greater } \\
\text { variation }\end{array}$ & $\begin{array}{c}\text { Smaller } \\
\text { variation }\end{array}$ & $\begin{array}{c}\text { Cases with } \\
\text { variation between } \\
90 \%-110 \%\end{array}$ & $\begin{array}{c}\text { Greater } \\
\text { variation }\end{array}$ & $\begin{array}{c}\text { Smaller } \\
\text { variation }\end{array}$ & $\begin{array}{c}\text { Cases with } \\
\text { variation between } \\
90 \%-110 \%\end{array}$ & $\begin{array}{c}\text { Greater } \\
\text { variation }\end{array}$ & $\begin{array}{c}\text { Smaller } \\
\text { variation }\end{array}$ & $\begin{array}{c}\text { Cases with } \\
\text { variation between } \\
90 \%-110 \%\end{array}$ \\
\hline
\end{tabular}

\begin{tabular}{|c|c|c|c|c|c|c|c|c|c|}
\hline Araraquara & $850 \%$ & $17 \%$ & 2 & $407 \%$ & $33 \%$ & 0 & $162 \%$ & $33 \%$ & 3 \\
\hline Bananal & $174 \%$ & $67 \%$ & 1 & $229 \%$ & $37 \%$ & 2 & $233 \%$ & $39 \%$ & 1 \\
\hline Campinas & $191 \%$ & $91 \%$ & 2 & $183 \%$ & $73 \%$ & 1 & $184 \%$ & $83 \%$ & 1 \\
\hline Franca & $172 \%$ & $46 \%$ & 3 & $276 \%$ & $51 \%$ & 1 & $242 \%$ & $33 \%$ & 1 \\
\hline Iguape & $136 \%$ & $78 \%$ & 0 & $73 \%$ & $61 \%$ & 0 & $111 \%$ & $50 \%$ & 0 \\
\hline
\end{tabular}

Note: The column "Cases with variation between $90 \%-110 \%$ " shows the number of observations for which the results calculated varied $10 \%$ more or less in relation to a perfect score.

Table 3 Type 1, 2, and 3 comparisons related to total revenue

(taking into account the active debts and balances and surpluses)

\begin{tabular}{|c|c|c|c|c|c|c|c|c|c|}
\hline \multirow[b]{2}{*}{ Municipalities } & \multicolumn{3}{|c|}{ Type 1 comparison } & \multicolumn{3}{|c|}{ Type 2 comparison } & \multicolumn{3}{|c|}{ Type 3 comparison } \\
\hline & $\begin{array}{c}\text { Greater } \\
\text { variation }\end{array}$ & $\begin{array}{c}\text { Smaller } \\
\text { variation }\end{array}$ & $\begin{array}{c}\text { Cases with } \\
\text { variation between } \\
\mathbf{9 0 \% - 1 1 0 \%}\end{array}$ & $\begin{array}{c}\text { Greater } \\
\text { variation }\end{array}$ & $\begin{array}{c}\text { Smaller } \\
\text { variation }\end{array}$ & $\begin{array}{c}\text { Cases with } \\
\text { variation between } \\
\mathbf{9 0} \%-\mathbf{1 1 0} \%\end{array}$ & $\begin{array}{c}\text { Greater } \\
\text { variation }\end{array}$ & $\begin{array}{c}\text { Smaller } \\
\text { variation }\end{array}$ & $\begin{array}{c}\text { Cases with } \\
\text { variation between } \\
\mathbf{9 0 \% - 1 1 0 \%}\end{array}$ \\
\hline Araraquara & $158 \%$ & $50 \%$ & 2 & $222 \%$ & $36 \%$ & 1 & $106 \%$ & $40 \%$ & 4 \\
\hline Campinas & $199 \%$ & $68 \%$ & 2 & $230 \%$ & $77 \%$ & 1 & $195 \%$ & $105 \%$ & 2 \\
\hline Franca & $223 \%$ & $8 \%$ & 4 & $198 \%$ & $29 \%$ & 1 & $489 \%$ & $12 \%$ & 0 \\
\hline Iguape & $282 \%$ & $20 \%$ & 1 & $79 \%$ & $40 \%$ & 0 & $159 \%$ & $31 \%$ & 0 \\
\hline
\end{tabular}

Note: The column "Cases with variation between $90 \%-110 \%$ " shows the number of observations for which the results calculated varied $10 \%$ more or less in relation to a perfect score. 
Type 1, 2, and 3 comparisons related to the total expenditure ${ }^{12}$

\begin{tabular}{|c|c|c|c|c|c|c|c|c|c|}
\hline \multirow[b]{2}{*}{ Municipalities } & \multicolumn{3}{|c|}{ Type 1 comparison } & \multicolumn{3}{|c|}{ Type 2 comparison } & \multicolumn{3}{|c|}{ Type 3 comparison } \\
\hline & $\begin{array}{c}\text { Greater } \\
\text { variation }\end{array}$ & $\begin{array}{c}\text { Smaller } \\
\text { variation }\end{array}$ & $\begin{array}{l}\text { Cases with variation } \\
\text { between } 90 \%-110 \%\end{array}$ & $\begin{array}{c}\text { Greater } \\
\text { variation }\end{array}$ & $\begin{array}{l}\text { Smaller } \\
\text { variation }\end{array}$ & $\begin{array}{l}\text { Cases with variation } \\
\text { between } 90 \%-110 \%\end{array}$ & $\begin{array}{c}\text { Greater } \\
\text { variation }\end{array}$ & $\begin{array}{c}\text { Smaller } \\
\text { variation }\end{array}$ & $\begin{array}{l}\text { Cases with variation } \\
\text { between } 90 \%-110 \%\end{array}$ \\
\hline Araraquara & $158 \%$ & $16 \%$ & 0 & $219 \%$ & $9 \%$ & 0 & $105 \%$ & $11 \%$ & 1 \\
\hline Bananal & $128 \%$ & $22 \%$ & 1 & $182 \%$ & $10 \%$ & 0 & $183 \%$ & $9 \%$ & 0 \\
\hline Franca & $149 \%$ & $24 \%$ & 1 & $211 \%$ & $15 \%$ & 0 & $538 \%$ & $38 \%$ & 0 \\
\hline Iguape & $207 \%$ & $66 \%$ & 1 & $73 \%$ & $49 \%$ & 0 & $100 \%$ & $75 \%$ & 1 \\
\hline
\end{tabular}

Note: The column "Cases with variation between $90 \%-110 \%$ " shows the number of observations for which the results calculated varied $10 \%$ more or less in relation to a perfect score.

The possibility that the large discrepancies found between budgeted values and actually collected or spent values were caused not by all, but by some headings, has led us to compare the various sources of revenue and expenses that make up the group of ordinary revenues and expenses. If this hypothesis was confirmed, perhaps researchers could rely on some specific headings observed in budgets and, thus, evaluating at least a limited portion of the financial history of municipalities. This way, we analyzed all revenue and expenditure headings, line by line, in a comparative study between budgeted and collected/spent values ${ }^{13}$. Again, we apply the methodology of comparing the financial statements of Year 1 to budgets of Years 1,2, and 3, and once again the results were discouraging.

We start from the expenditure perspective, because these records contained a series of regular expenses provided by law as a responsibility of municipal governments. Moreover, when compared to revenue records, the expenses had a greater number of matches between the headings included in budgets and those included in handwritten financial statements.

The expenses that had the "best" behavior were those related to wages and bonuses. Regarding Iguape, Araraquara, and Campinas, almost always budgeted values were equal to effectively spent values. However, for the towns of
Bananal and Franca, they were rarely equal. The budgeted heading that reached higher values in any year and taking into account any town was that of public works. Well, considering this heading, no correspondence was found between budgets and financial statements for any of the towns and none of the years within the period. One of the expenses that was never included in any budget law, but it was always included in financial statements was the percentage paid to the prosecutor, who was the tax collector of the municipality, because this position was paid on the basis of a commission on the values of taxes and fees actually collected. For another great set of expenses, those related to law enforcement, such as spending on legal fees, feeding of poor prisoners, and prison lighting, no correlation was found, too, between financial statements and budgets for subsequent years.

Such results, summarized in Table 5, show that budgets of some locations were better prepared than others, in order to incorporate, at least in some headings, the past experience registered in financial statements. Success, in this sense, may be noticed in spending on wages and bonuses of municipal public service officials. In the same Table 5 wage costs are separated from those not related to wage, in order to show that there was almost no correlation between financial statements and budgets in the case of non-wage expenditure.

Table 5

Spending details

\begin{tabular}{|c|c|c|c|c|c|}
\hline Municipality & Spending detail & $\begin{array}{c}\text { Number of comparable } \\
\text { observations }\end{array}$ & $\begin{array}{c}\text { Number of observations for } \\
\text { which values match }\end{array}$ & $\begin{array}{c}\text { Matches } \\
(\%)\end{array}$ & $\begin{array}{c}\text { Interval between statement } \\
\text { and budget }\end{array}$ \\
\hline Araraquara & $\begin{array}{l}\text { Total expenditure } \\
\text { non-wage expenditure } \\
\text { non-wage expenditure }\end{array}$ & $\begin{array}{l}60 \\
15 \\
45 \\
\end{array}$ & $\begin{array}{c}21 \\
15 \\
6 \\
\end{array}$ & $\begin{array}{c}35.0 \% \\
100.0 \% \\
13.3 \% \\
\end{array}$ & two years \\
\hline Bananal & $\begin{array}{l}\text { Total expenditure } \\
\text { non-wage expenditure } \\
\text { non-wage expenditure }\end{array}$ & $\begin{array}{l}79 \\
27 \\
52 \\
\end{array}$ & $\begin{array}{l}4 \\
2 \\
2 \\
\end{array}$ & $\begin{array}{l}5.1 \% \\
7.4 \% \\
3.8 \% \\
\end{array}$ & one year \\
\hline Campinas & $\begin{array}{l}\text { Total expenditure } \\
\text { non-wage expenditure } \\
\text { non-wage expenditure }\end{array}$ & $\begin{array}{l}71 \\
31 \\
40 \\
\end{array}$ & $\begin{array}{c}33 \\
28 \\
5 \\
\end{array}$ & $\begin{array}{l}46.5 \% \\
90.3 \% \\
12.5 \% \\
\end{array}$ & two years \\
\hline Franca & $\begin{array}{l}\text { Total expenditure } \\
\text { non-wage expenditure } \\
\text { non-wage expenditure }\end{array}$ & $\begin{array}{l}81 \\
29 \\
52 \\
\end{array}$ & $\begin{array}{l}2 \\
0 \\
2 \\
\end{array}$ & $\begin{array}{l}2.5 \% \\
0.0 \% \\
3.8 \% \\
\end{array}$ & one year \\
\hline Iguape & $\begin{array}{l}\text { Total expenditure } \\
\text { non-wage expenditure } \\
\text { non-wage expenditure }\end{array}$ & $\begin{array}{l}68 \\
28 \\
40 \\
\end{array}$ & $\begin{array}{c}32 \\
23 \\
9 \\
\end{array}$ & $\begin{array}{l}47.1 \% \\
82.1 \% \\
22.5 \% \\
\end{array}$ & one year \\
\hline
\end{tabular}

There were so few cases in which the ordinary expense was different from total expenditure that we have chosen to work only with the latter. This is due to the small number of observations related to passive debt, both in the budgets and financial statements taken into account.

Nevertheless, it is worth noticing that not all headings observed in budgets could be identified in financial statements, and vice versa. 
If budgeted expenses, many of them routine and predictable, have not been adjusted over the years based on the financial statements of previous financial years, it might be even less likely that revenues were. This is so because all revenues named by us as ordinary revenue consisted of a number of taxes and fees on urban trade activities and fines for failure to comply with municipal legislation. Nowadays, it is very difficult to predict with great accuracy a future economic activity, even with all the technology at our disposal. Let us imagine the possibility to predict a future activity - which served as the basis of public revenues - in the $19^{\text {th }}$ century. Even by using a methodology developed to budget revenues, forecasts on the consumption of goods and services and the likelihood of failure to comply with municipal legislation were not much better than mere guesswork. In this case, it would be reasonable for the historian to assume that financial statements were very useful at the time of preparing budgets. However, in few cases some correlation was identified.

According to Table 6, the town of Araraquara had two good years when the financial statements of Year 1 beca- me the budgeted values for Year 3, a result that could allow using budgets as a means to bring closer the values provided in previous financial years. Nevertheless, unfortunately, this was the exception that confirmed the rule ${ }^{14}$. The income sources observed in financial statements of Campinas accounts matched with future budgets in around 25\% of headings; for Franca, matches badly reached 12\%; and for Iguape this percentage was calculated at only $5.6 \%$ of revenues. Curiously, the only heading whose value was supposed to be removed from financial statements and included in the subsequent budget - balances and surpluses from the previous year - had only 9 matches out of a total of 25 observations ${ }^{15}$.

We also cannot offer historians a suggestion regarding time interval, 1 or 2 years, between financial statement and its use as a means in the preparation of future budgets. Three of our cases, Bananal, Franca, and Iguape, pointed out some correlations between financial statement of Year 1 and budget of Year 2, i.e. one year apart. The two other cases, Araraquara and Campinas, showed some correlation between final statement of Year 1 and budget of Year 3, i.e. an interval of two years.

Table 6

Revenue details

\begin{tabular}{|c|c|c|c|c|c|}
\hline Municipality & Spending detail & $\begin{array}{c}\text { Number of comparable } \\
\text { observations }\end{array}$ & $\begin{array}{l}\text { Number of observations } \\
\text { for which values match }\end{array}$ & $\begin{array}{c}\text { Matches } \\
(\%)\end{array}$ & $\begin{array}{l}\text { Interval between } \\
\text { statement and budget }\end{array}$ \\
\hline \multirow[t]{2}{*}{ Araraquara } & Total revenue & 52 & 27 & $51.9 \%$ & \multirow{2}{*}{ two years } \\
\hline & derived from balances and surpluses & 7 & 2 & $28.6 \%$ & \\
\hline \multirow[t]{2}{*}{ Campinas } & Total revenue & 52 & 13 & $25.0 \%$ & \multirow{2}{*}{ two years } \\
\hline & derived from balances and surpluses & 5 & 3 & $60.0 \%$ & \\
\hline \multirow[t]{2}{*}{ Franca } & Total revenue & 41 & 5 & $12.2 \%$ & \multirow{2}{*}{ one year } \\
\hline & derived from balances and surpluses & 7 & 2 & $28.6 \%$ & \\
\hline \multirow[t]{2}{*}{ Iguape } & Total revenue & 36 & 2 & $5.6 \%$ & \multirow{2}{*}{ one year } \\
\hline & derived from balances and surpluses & 6 & 2 & $33.3 \%$ & \\
\hline
\end{tabular}

Note: We do not have revenue details for the town of Bananal.

\section{FINAL REMARKS}

We started this journey with the initial primary question: why is there a seemingly irreconcilable difference in the results of two surveys, both based on municipal finances? This difference, with its repercussion for interpreting the past, has led us to ask about our reliance on primary sources, and urged us to investigate. We evaluated the two types of sources to verify agreement and disagreement points. As few agreement points were observed in the budgeted values (ex-ante) and provided values (ex-post), a result that suggested the non-viability of using budgets to study the $19^{\text {th }}$ century municipal economic and financial history, we tried to design a methodology that allowed resuming the usefulness of this source. We used lags of 1,2 , and 3 years to compare broad categories of income and expense both as specific titles, in order to identify patterns that could be applied to bridge the gap between budgeted and provided values. We did not find any. Our hypothesis that the practice of preparing budgets had the effect of improving its ability to meet future results was lacking. In this journey into

The financial statements of Araraquara accounts for the years 1842 and 1844 were used as a basis for the preparation of budgets for 1844 and 1846, respectively. There was a perfect coincidence between the figures reported. Financial statements of two additional years, 1840 and 1846, also served as the basis for the preparation of budgets for 1840 and 1846, respectively, but in this case there is no complete correlation between headings and values, since there was no match between two "Jokers" of municipal public accounting in the $19^{\text {th }}$ century: active debts and balances and surpluses.

These observations correspond to all the cases, except Bananal. There were two matches for each town, except Franca, which had three. In other words, no municipality was better than other in incorporating the knowledge gained from financial statements to prepare budgets. 
the strange world of historical accounting, we learned that budgets rarely reflected the actual financial status of municipalities. Local administrators did not correctly predicted their revenue or their expenses for a given year, and more, they did not use the past results as a means to better predict future economic performance.

In the best scenario, budgets reflected the optimism of the members of the Committee on Budget and Finance of the Provincial Legislative Assembly. In the worst, budgets reflected the cynicism of the same members, which reviewed financial statements and, therefore, were aware of the actual situation of revenue sources and rather relevant expenses - active debts and public works - and they kept approving budgets that had little to do with reality. The latter scenario is more likely, given the care that this committee had to analyze the municipal financial issues (Hanley, 2013).

Our analysis showed that, for analyzing public finance or the economic daily life of the São Paulo state municipalities during the $19^{\text {th }}$ century, historians may not rely on published budget laws. This finding is important because it demonstrates that administrators either poorly estimated the resources available to provide the population with the needed public services or they were very inefficient in collecting what was owed to the municipality. The overall result was non-payment of some bills - even wages of public service officials indicated by the local patronage - and failure in the provision of public goods.

Our purpose is warning the historians who are attracted to use published budget laws, since they are easily accessible and easy to understand. Such budgets were somewhere around $10 \%$ to $500 \%$ far from the actual financial status of a municipality. These variations should make any economist or public accountant uncomfortable, especially due to the fact that these variances do not have any kind of pattern, something which prevents the application of some corrective methodology in order to adjust these values. Thus, published budgets should not be used without the understanding that they describe a highly inaccurate setting of the $19^{\text {th }}$ century municipal public finance.

\section{References}

Buescu, M. (1984). Organização e administração do Ministério da Fazenda no Império (vol. 13). Brasília, DF: Funcep.

Burrows, G., \& Cobbin, P. E. (2011). Budgetary and financial discontinuities: Iraq, 1920-1932. Accounting History Review, 21(3), 247-262. doi: 10.1080/21552851.2011.616716

Camargo, J. F, (1981). Crescimento da população no Estado de São Paulo e seus aspectos econômicos (vol. 1). São Paulo: IPE/USP.

Carvalho, J. M. (2003): A construção da ordem: a elite política imperial; Teatro de sombras: a política imperial. Rio de Janeiro: Record.

Carreira, L. C. (1889). História financeira e orçamentária do Império do Brazil desde a sua fundação, precedida de alguns apontamentos acerca da sua independência. Rio de Janeiro: Imprensa Nacional.

Castro, A. O. (1989). História tributária do Brasil. Brasília, DF: Esaf.

Cunha, P. O. C. (1973). Política e administração de 1640 a 1763. In S. B. Holanda, História geral da civilização brasileira (vol. 2). São Paulo: Difusão Europeia do Livro.

Danieli, M. I. B. C. (2006). Economia mercantil de abastecimento e rede tributária: São Paulo, séculos XVIII e XIX (Tese de Doutorado). Universidade Estadual de Campinas, Campinas.

Deveza, G. (1971). Política tributária no período imperial. In S. B Holanda, História geral da civilização brasileira (vol, 6). São Paulo: Difusão Europeia do Livro.

Dolhnikoff, M. (2005). O pacto imperial. São Paulo: Globo.

Fleiuss, M. (1925). História administrativa do Brasil (2a ed.). Rio de Janeiro: Imprensa Nacional.

Giosi, A. (2007). Considerations on the evolution of the national budget functions: from internal relevance to external value. Accounting, Business \& Financial History, 17(1), 63-85.

Gomes, D., \& Sargiacomo, M. (2013). Accounting and accountability in local government: an introduction. Accounting History, 18(4), 439-446.
Graham, R. (1977). Government expenditures and political change in Brazil, 1880-1889. Journal of Interamerican Studies and World Affairs, 19(3), 339-368.

Hanley, A. G. (2013). A failure to deliver: municipal poverty and the provision of public services in imperial São Paulo, Brazil 1822-1889. Journal of Urban History, 39(3), 513-535.

Hanley, A. G., \& Lopes, L. S. (2012). Can public accounts be trusted? Evidence from the historical record in São Paulo, Brazil 1835-1850. In $11^{\text {th }}$ International Congress of the Brazilian Studies Association. Úrbana/Champaign, IL: University of Illinois.

Lopes, L. S. (2011). Ribeirão Preto: a dinâmica da economia cafeeira de 1870 a 1930. Ribeirão Preto, SP: Fundação Instituto do Livro.

Montoro, E. A. F. (1974). A organização do município na federação brasileira (Tese de Doutorado). Pontifícia Universidade Católica de São Paulo, São Paulo.

Nozoe, N. H. (1984). São Paulo: economia cafeeira e urbanização. São Paulo: IPE/USP.

Nozoe, N. H. (2004). Vida econômica e finanças municipais da capital paulista na época imperial. In P. Porta, História da cidade de São Paulo. A cidade no Império, 1823-1889 (pp. 131-151). São Paulo: Paz e Terra.

Pires, J. M. (1994). Em estudo de história econômica regional sob a ótica das finanças públicas. São Paulo: [s.n.].

Taunay, A. (1974). História Administrativa do Brasil. A administraçã̀o manuelina. In H. A. Avellar, História administrativa do Brasil. Rio de Janeiro: Departamento Administrativo de Serviço Público.

Tessitore, V. (1995). As fontes da riqueza pública: tributos e administração tributária na Província de São Paulo (1832-1892). São Paulo: FFLCH/USP.

Villela, A. (2007). Distribuição regional das receitas e despesas do Governo Central no II Reinado, 1844-1889. Estudos Econômicos, 37(2), 247-274. 